MEDIKA ALKHAIRAAT : JURNAL PENELITIAN KEDOKTERAN DAN KESEHATAN 3(3):89-93

e-ISSN: 2656-7822, p-ISSN: 2657-179X

\title{
AKTIVITAS ANTI-BIOFILM BAKTERI DARI PRODUK ALGA COKLAT Dictyota sp.
}

\author{
Muhammad Ardi Afriansyah $^{1^{*}}$, Mudyawati Kamaruddin ${ }^{2 *}$, Stalis Norma Ethica ${ }^{2}$, Nurannisa \\ Fitria Aprianti ${ }^{3}$ \\ ${ }^{1}$ Program Studi Diploma Teknologi Laboratorium Medik Universitas Muhammadiyah Semarang, \\ Jalan Kedungmundu 18 Semarang Jawa Tengah, Indonesia \\ ${ }^{2}$ Program Pascasarjana Ilmu Laboratorium Medik Universitas Muhammadiyah Semarang, Jalan \\ Kedungmundu 18 Semarang Jawa Tengah, Indonesia \\ ${ }^{3}$ Program Studi Sarjana Kebidanan, STIKES Hamzar Memben Lombok Timur, Indonesia \\ Corresponding author: Telp: +628114120603, email: afriansyah@unimus.ac.id; \\ mudyawati@unimus.ac.id
}

\begin{abstract}
ABSTRAK
Infeksi bakteri dapat memperlambat penyembuhan, menyebabkan deformitas dan kematian sel. Hal ini disebabkan bakteri menghasilkan biofilm yang memberikan sifat resistensi terhadap antibiotik yang diberikan pada luka yang terinfeksi bakteri itu. Infeksi yang terkait dengan biofilm merupakan mayoritas dari semua infeksi bakteri yang kronis atau berulang dalam tubuh manusia. Alginat liase.merupakan enzim yang mampu mendegradasi alginat, yang merupakan komponen utama biofilm bakteri. Oleh karena itu, pencarian sumber baru alginat liase menjadi penting dalam pemberantasan penyakit infeksi terutama yang terkait dengan pembentukan biofilm. Penelitian ini bertujuan untuk mengetahui kemampuan simbion dari produk fermentasi alga coklat Dictyota sp. yang diperoleh dari Teluk Awur, Jepara, Indonesia dalam mendegradasi biofilm bakteri. Sampel makroalga segar difermentasi terlebih dahulu selama 7 hari untuk merangsang aktivitas degradasi oleh bakteri simbion secara umum. Data yang diperoleh dari hasil kultur dan resistensi dapat dijadikan sebagai dasar dilakukan terapi empiris. Bakteri simbion Dictyota sp ditumbuhkan pada media Zobell Agar (ZA) dan kemudian masing-masing koloni spesifik yang tumbuh dimurnikan menggunakan media Nutrient Agar (NA). Agar minimal alginat kemudian digunakan sebagai media selektif untuk mendeteksi keberadaan bakteri alginolitik yang ditunjukkan dengan kemampuannya membentuk zona alginolitik yang jernih disekitar koloni bakteri. Dari 14 isolat bakteri simbion Dictyota sp, 3 yaitu FD-01, FD-03, dan FD-04, dapat menghasilkan zona alginoliti dengan nilai indek alginolitik berkisar antara 0,5 - 1,0. Kesimpulannya, Dictyota sp. merupakan sumber potensial bakteri penghasil enzim antibiofilm, alginat liase.
\end{abstract}

Kata Kunci: Biofilm Bakteri, Alginate Lyase, Dictyota sp

\section{ABSTRACT}

Infections associated with biofilm comprises approximately the most percentage of all chronic and recurrent bacterial infections in the human body. Biofilms could make bacterial cells to have multiplied antibiotics resistance. Alginate lyase is an enzyme capable of degrading alginate, the main component of bacterial biofilm. Therefore, the search of new sources of alginate lyase has the importance in the eradication of infection diseases, particularly those involving biofilm formation. This work aimed to isolate bacteria from fermented product of brown algae Dictyota sp. from Teluk Awur, Jepara, Indonesia and screen for their ability to degrade alginate. Fresh macroalgae sample was first fermented for 7 days to stimulate general degradation activities. After serial dilution, bacteria symbiont Dictyota sp product were first grown on Zobell Agar (ZA) media, and then each of the unique grown colonies was purified using Nutrient Agar (NA) media. Alginate minimal agar was then used as selective media to detect the presence of alginolytic bacteria indicated by the ability to form clear 
alginolytic zone around bacterial colonies. As results, 14 unique colonies of bacteria could be isolated and purified from bacteria symbiont Dictyota sp. 3 of them, FD-01, FD-03, and FD04, could produce alginolytic zone with alginolytic index between $0.5-1.0$. As conclusion, Dictyota sp. appeared to be a potential source of bacteria producing antibiofilm enzyme, alginate lyase.

Keywords: Bacteri biofilm, Alginate Lyase, Dictyota sp

\section{PENDAHULUAN}

Telah banyak penyakit infeksi kronis mematikan penyebab penderitaan manusia dan kerugian ekonomi yang besar di zaman modern ini yang disebabkan oleh biofilm bakteri. Pembentukan biofilm oleh bakteri infeksius merupakan salah satu faktor utama yang menyebabkan prognosis kasus infeksi menjadi rumit. ${ }^{1}$

Keadaan ini diperburuk oleh evolusi yang terus menerus dari bakteri penyebab infeksi serta berkembangnya sifat resistensi terhadap antibiotik yang disebabkan biofilm. Oleh karena itu, pengembangan produk baru yang memiliki aktivitas antibiofilm menjadi sangat penting. $^{2}$

Biofilm adalah komunitas mikroorganisme yang menempel pada suatu permukaan, yang terbungkus dalam suatu matrik zat polimer ekstraseluler penyumbang setidaknya $80 \%$ volume biofilm. Biofilm umumnya tersusun dari polisakarida, protein, glikolipid, kepingan darah dan komponen seluler, enzim ekstraseluler, ion logam, serta DNA ekstraseluler. ${ }^{3}$ Biofilm memungkinkan bakteri untuk bertahan hidup di lingkungan yang tidak bersahabat. Bakteri pembentuk biofilm menjadi sulit untuk dibasmi karena strukturnya yang padat dan kompleks menghambat penetrasi dan akses menuju sel patogen, membuatnya sangat tahan terhadap kondisi stres, dan juga senyawa-senyawa antibiotik. $^{4}$

Komponen polisakarida penyusun biofilm pada umumnya adalah senyawa alginat. Sedangkan senyawa alami pendegradasi alginate adalah suatu enzim yang disebut alginate Liase. Karena kemampuannya mendepolimerasi komponen polisakarida utama biofilm, maka enzim alginate Liase sering disebut sebagai senyawa antibiofilm.
Mikroorganisme yang berasosiasi dengan makhluk hidup yang mendiami perairan laut, biasanya memiliki potensial metabolit sekunder yang adekuat, ${ }^{5,6}$ seperti bakteri yang berasosiasi dengan alga coklat seringkali memiliki kemampuan mendegradasi alginat dengan menghasilkan enzim alginate liase. Oleh karena itu isolasi bakteri pendegradasi alginat pada alga coklat berpotensi memberikan temuan berupa senyawa antibiofilm yang baru.

Dictyota sp. adalah alga coklat yang banyak dikonsumsi secara lokal di kawasan Karibia, Melayu-Indonesia dan Hawaii. Ekstrak alga Dictyota sp. yang mengandung senyawa aktif, seperti diterpen dan florotanin, telah dikaitkan dengan efek antimikrobia, kesehatan dan kebugaran yang menjadikannya kandidat yang menjanjikan untuk desain makanan fungsional, produk fitomedisinal, serta kosmetik. ${ }^{7}$ Kandungan alginat pada Dictyota sp. dari Indonesia telah dilaporkan pada tahun 2009 sebesar 14,85 $15,92 \%$. Kandungan alginat pada Dictyota $s p$. ini memungkinkan ditemukannya bakteri simbion alga coklat tersebut yang mampu menghasilkan senyawa antibiofilm, alginat Liase. Artikel ini melaporkan keberadaan bakteri alginolitik (pendegradasi alginate) yang diperoleh dari sampel produk fermentasi Dictyota sp. yang diambil dari perairan Teluk Awur, Jawa Tengah, Indonesia.

\section{METODOLOGI}

Sampel Dictyota $s p$. diperoleh dari perairan Teluk Awur, Jepara, Jawa Tengah dan disimpan dalam ice-box. ${ }^{8}$ Sampel alga segar difermentasi $(1,25 \mathrm{~g}$ garam krosok, $0,5 \mathrm{~g}$ gula aren, 5g alga coklat) pada suhu ruang selama 7 hari. Sebanyak $100 \mu$ suspensi pengenceran 10-1 - 10-5 hasil fermentasi 
Dictyota sp. ditanam pada media Zobel Marine Agar (ZMA) dan dinkubasi selama 24 jam pada suhu $37^{\circ} \mathrm{C}$. koloni yang tumbuh menunjukkan karakteristik berbeda kemudian dilakukan pemurnian menggunakan Nutrient Agar (NA). Total 14 isolat yang diperoleh dari hasil fermentasi Dictyota sp. diuji skrining untuk mengetahui adanya aktivitas alginat liase.

Aktivitas alginat Liase secara kualititatif, dapat terlihat pada pembentukan zona bening disekeliling bakteri menunjukkan adanya aktivitas alginat liase. Diameter zona bening dan diameter koloni diukur, dan aktivitas alginat liase dinyatakan sebagai indeks alginolitik yang merupakan perbandingan antara diameter zona bening dibagi dengan diameter koloni bakteri.

\section{HASIL DAN PEMBAHASAN}

Enzim liase yang spesifik mampu mendegradasi senyawa matriks polimerik ekstraselular pada biofilm. Total 14 isolat berhasil diperoleh dan terdapat 3 isolat diantaranya positif yang ditunjukkan oleh terbentuknya zona bening disekeliling koloni setelah dituang larutan lugol atau teridentifikasi sebagai bakteri yang menghasilkan alginat liase. Ketiga bakteri yang ditampilkan ini merupakan kelompok bakteri Gram-positif berbentuk batang (basil) dan menunjukkan karakteristik koloni yang khas (Tabel 1). Keberadaan isolat FD-01, FD-03, dan FD-04 yang berbentuk batang serta isolat FD-01 dan FD-03 yang memiliki spora tampak pada Tabel 1 tersebut.

Tabel 1. Morfologi koloni bakteri penghasil alginate Liase

\begin{tabular}{lccc}
\hline $\begin{array}{l}\text { Kode } \\
\text { Isolat }\end{array}$ & Bentuk & Spora & Sifat \\
\hline FD-01 & Batang & + & Gram + \\
\hline FD-03 & Batang & + & Gram + \\
\hline FD-04 & Batang & - & Gram + \\
\hline
\end{tabular}

Nilai indek alginolitik dari 3 isolat ini berkisar antara 0,5 - 1.0 (Tabel 2). FD-01 memiliki nilai indek alginolitik yang paling tinggi $(1,0)$, dibandingkan dengan isolat FD03 dan FD-04 dengan nilai indek alginolitik masing-masing sebesar 0,8 dan 0,5 .

Tabel 2. Indek alginolitik bakteri penghasil alginate liase

\begin{tabular}{clc}
\hline $\begin{array}{c}\text { Isolat } \\
\text { Bakteri }\end{array}$ & \multicolumn{1}{c}{ Karakteristik } & $\begin{array}{c}\text { Indek } \\
\text { Algin } \\
\text { olitik } \\
(\mathrm{mm})\end{array}$ \\
\hline \multirow{3}{*}{ FD-01 } & $\begin{array}{l}\text { Bulat, warna krem, } \\
\text { tepi rata/entire, } \\
\text { elevasi cembung, } \\
\text { konsistensi kasar. }\end{array}$ & 1,0 \\
\hline \multirow{3}{*}{ FD-03 } & $\begin{array}{l}\text { Bulat, warna krem, } \\
\text { tepi tidak } \\
\text { rata/undulate, } \\
\text { elevasi cembung, } \\
\text { konsistensi kasar. }\end{array}$ \\
\hline & $\begin{array}{l}\text { Bulat, warna krem, } \\
\text { tepi rata/entire, } \\
\text { elevasi cembung, } \\
\text { konsistensi halus. }\end{array}$ \\
\hline FD-04 0,5 \\
\hline
\end{tabular}

Nilai indek alginolitik dapat digunakan sebagai acuan adanya aktivitas alginat liase atau besaran enzim yang dapat diproduksi oleh bakteri. Semakin tinggi nilai indek alginolitik menunjukkan aktivitas alginat liase yang tinggi dan dapat artikan bahwa bakteri dapat memproduksi enzim algiate liase dalam jumlah besar namun hal tersebut dapat dipengaruhi beberapa faktor seperti lingkungan tempat tinggal bakteri, usia bakteri, suhu penyimpanan serta tersedianya nutrisi yang cukup untuk melakukan produksi enzim 9 . Beberapa penelitian sebelumnya telah menggunakan metode seperti ini untuk menyeleksi bakteri penghasil alginat liase. Peneltian yang dilakukan oleh Subaryono et al., 2015. melaporkan empat isolat positif penghasil alginat liase yang diperoleh dari sampel fermentasi Sargassum crassifolium. Ke empat isolat tersebut menujukkan indek alginolitik berkisar antara 2,85-3,78. 
Alginat Liase merupakan jenis enzim degradasi yang ditemukan pada organime yang memiliki sistem metabolisme alginat seperti Dictyota sp. Dictyota sp. merupakan sumber utama alginat laut melibatkan simbion bakteri laut yang secara aktif terlibat dalam proses ekskresi enzim alginate. ${ }^{10}$ Liase alginat diketahui memiliki potensi yang sangat besar bagi dunia industri terutama obat-obatan jenis biokatalisis produksi oligosakarida yang memiliki bioaktivitas khusus. ${ }^{11}$ Isolasi mikroorganisme penghasil alginat liase menggunakan medium minimal yang mengandung subtrat alginat sehingga kemunculan zona bening menandakan bakteri meggunakan alginat sebagai sumber karbon 12 .

Aplikasi alginate liase dalam industri farmasi dapat digunakan sebagai agen antibiofilm. selain itu, alginat Liase dapat dimanfaatkan sebagai bahan pembuatan biofuel, biofertilizer, dan produk pertanian seperti pupuk hayati, serta yang paling potensial dari aplikasi enzim ini yaitu alginate olygoshacharides (AOS) sebagai immunomodulator alami untuk merangsang peningkatan sistem imun ${ }^{13}$.

Biofilm tersusun dari eksopolisakarida bakteri yang melekat secara ireversibel pada suatu permukaan yang terbungkus dalam matriks Extracelullar Polymeric Substances (EPS) dan material capsular yeast yang meghasilkan lapisan pelindung sehingga tahan terhadap paparan antibiotika dan desinfektan. Infeksi mikroba yang membentuk biofilm akan sulit ditangani dengan obat-obatan seperti antibiotik atau antimikroba meskipun pada keadaan tertentu terdapat aplikasi biofilm yang bermanfaat. Dalam biofilm, bakteri dapat tumbuh dan berkembangbiak karena tersedia nutrisi yang cukup untuk pertumbuhan. ${ }^{14}$

Pembentukan antibiofilm membuat bakteri menjadi resisten terhadap antibiotika. Telah banyak kasus bacterial multi-drug resistant (MDR) yang salah satunya disebabkan oleh pembentukkan biofilm bakteri. Biofilm merupakan suatu mekanisme pertahanan diri bakteri terhadap kondisi lingkungan yang mengancam dirinya. Pembentukkan biofilm dapat menghambat penetrasi antibiotik melalui mekanisme pertahanan yaitu perubahan tekanan osmotik melalui penyempitan porin, penghambatan difusi dari susbtansi dan mengikat antibiotik sehingga senyawa antibiotik tidak dapat masuk kedalam sel untuk membunuh bakteri. ${ }^{15}$

Aplikasi enzim pendegradasi alginat atau alginat liase diketahui efektif dalam merusak struktur biofilm. Matriks film pada biofilm tersusun dari alginat sehingga dengan pemberian enzim pedegradasi alginat dapat merusak struktur matriks penyusun biofilm. Proses ini mirip dengan mekanisme selfdestruction yang terjadi apabila kurangnya ketersediaan nutrisi pada biofilm. Mekanisme ini juga dapat terjadi akibat adanya peran gen tertentu misalnya ekspresi gen alg. ${ }^{16}$

Pencarian sumber alginat liase masih perlu dilakukan karena kebutuhan agen antibiofilm yang terus meningkat. Pada aplikasi bidang instrumentasi biomedis, alginat liase telah diimobilisasi menggunakan strategi coating pada polikarbonat lalu digunakan dalam perangkat medis seperti kartrid filter untuk dialisis, dan oksigenator darah untuk mencegah infeksi akibat implantasi alat-alat tersebut. ${ }^{17}$ Dictyota sp. adalah salah satu sumber penghasil alginat liase. Pada penelitian ini bakteri penghasil enzim alginat liase dapat diperoleh dan perlu diuji lebih lanjut terkait potensinya sebagai agen antibiofilm bakteri patogen.

\section{SIMPULAN DAN SARAN}

Hasil penelitian ini menunjukkan bahwa Dictyota sp. merupakan sumber potensial bakteri yang memproduksi senyawa antibiofilm yaitu enzim alginat liase. Sebanyak 3 dari 14 isolat bakteri yang berhasil dikulturkan dari produk fermentasi alga coklat tersebut mampu menghasilkan zona degradasi pada media alginat agar. 


\section{DAFTAR PUSTAKA}

1. Gonzalez JF, Hahn MM, and Gunn JS. Chronic biofilm-based infections: skewing of the immune response. Pathogens and disease. 2018;76(3).

2. Cordeiro L, Figueiredo P, Souza H, Sousa A, Andrade-Junior F, Barbosa-Filho J and Lima E. Antibacterial and Antibiofilm Activity of Myrtenol Against Staphylococcus aureus. Pharmaceuticals. 2020;13(6): 133.

3. Gutierrez TJ. Antibiofilm enzymes as an emerging technology for food quality and safety in Enzymes in Food Biotechnology. Academic Press. 2019; 321-342.

4. Muhammad MH, Idris AL, Fan X, Guo $\mathrm{Y}, \mathrm{Yu} \mathrm{Y}$, Jin X, and Huang T. Beyond risk: Bacterial biofilms and their regulating approaches. Frontiers in microbiology. 2020; 11, 928.

5. Marzuki I, Kamaruddin M, Ahmad R. Identification of marine spongessymbiotic bacteria and their application in degrading polycyclic aromatic hydrocarbons. Biodiversitas. 2021;22(3):1481-1488. doi:10.13057/BIODIV/D220352

6. Kamaruddin M, Marzuki I, Burhan A, Ahmad R. Screening acetylcholinesterase inhibitors from marine-derived actinomycetes by simple chromatography. IOP Conf Ser Earth Environ Sci. 2021;679(1):012011. doi:10.1088/1755-1315/679/1/012011

7. Bogaert KA, Delva S, and De Clerck O. Concise review of the genus Dictyota JV Lamouroux. Journal of Applied Phycology. (2020; 32, 1521-1543.

8. Ethica SN, Muchlissin SI, Saptaningtyas $\mathrm{R}$, and Sabdono A. Sampling mikrobiologi limbah biomedis rumah sakit di kota Semarang Jawa Tengah. Prosiding Seminar Nasional \& Internasional. 2017; 1(1).
9. Subaryono $\mathrm{S}$, Peranginangin $\mathrm{R}$, Suhartono MT, Zakaria FR. Isolasi dan Identifikasi Bakteri Penghasil Alginat Lyase dari Rumput Laut Sargassum crassifolium. J Pascapanen dan Bioteknol Kelaut dan Perikan. 2015;10(1):1. doi:10.15578/jpbkp.v10i1.239

10. Inoue A, Ojima T. Functional identification of alginate lyase from the brown alga Saccharina japonica. Sci Rep. 2019;9(1):1-11. doi:10.1038/s41598-01941351-6

11. Zhang C, Kim SK. Research and application of marine microbial enzymes: Status and prospects. Mar Drugs. 2010;8(6):1920-1934. doi:10.3390/md8061920

12. Tavafi H, Abdi-Ali A, Ghadam P, Gharavi S. Screening of alginate LyaseProducing bacteria and optimization of media compositions for extracellular alginate Lyase production. Iran Biomed $J$. 2017;21(1):48-56. doi:10.18869/acadpub.ibj.21.1.48

13. Subaryono S, Peranginangin R, Suhartono MT, Zakaria FR. Alginate Lyases: Sources, Mechanism of Activity and Potencial Application. Squalen Bull Mar Fish Postharvest Biotechnol. 2013;8(3):105. doi:10.15578/squalen.v8i3.39

14. Purbowati R. Hubungan Biofilm dengan Infeksi: Implikasi pada Kesehatan Masyarakat dan Strategi Mengontrolnya. J Ilm Kedokt Wijaya Kusuma. 2018;5(1):1. doi:10.30742/jikw.v5i1.1

15. Gunardi WD. Peranan biofilm dalam kaitannya dengan penyakit infeksi. $J$ Kedokt Meditek. 2014;15(6):1-9.

16. Homenta H. Infeksi Biofilm Bakterial. J e-Biomedik. 2016;4(1):1-11. doi:10.35790/ebm.4.1.2016.11736.

17. Kurtz SM. Retrieval analysis of a polycarbonate-urethane acetabular cup: a case report. Journal of long-term effects of medical implants. 2008;18(1). 